\title{
Green living envelopes for food and energy production in cities
}

\author{
D. Roehr \& J. Laurenz \\ greenskinslab, Design Centre for Sustainability, School of Architecture \\ and Landscape Architecture, The University of British Columbia, Canada
}

\begin{abstract}
This research explores the potential benefits derived from a proposed green intervention which combines living envelopes (green roofs and green façades) and green energy envelopes (photovoltaic and thermal panels), as a means of addressing the concept of carbon neutral cities. It proposes to take advantage of the environmental contributions that living envelopes provide, in terms of food production and the reduction of energy demand; as well as the energy produced through green energy envelopes such as photovoltaic and thermal panels.

This green living envelopes intervention is applied to a specific site of downtown Vancouver, Canada. The research explores the contribution of such a green intervention. It analyses existing conditions of the site in terms of different building types and uses as well as their current energy consumption and $\mathrm{CO}_{2}$ emissions. It then proposes to incorporate living envelopes such as green roofs and façades, as well as green energy envelopes by applying the proposed Vancouver Green Factor.

Achieved findings from such a green intervention shows that the total energy consumed by buildings by the greening of roofs and façades would be reduced by $17 \%$. In addition, energy produced through photovoltaic and thermal panels is enough to cover $16 \%$ of the energy demand. Moreover, by using green roofs as food producers, $54 \%$ of the vegetable demand of the people living in the selected site would be covered, further contributing to a reduction of $4 \%$ of the total food production. This translates into a reduction of $45 \%$ of $\mathrm{CO}_{2}$ emissions produced by the selected site.

Keywords: living envelopes, green roofs, green façades, green energy, energy savings, $\mathrm{CO}_{2}$ emissions, green houses, urban agriculture, energy production, carbon neutrality.
\end{abstract}




\section{Introduction}

The city is the solution (Lerner [1]) for one of the major challenges of our time. Cities are responsible for major health and hygienic problems, and the quality of urban environments defines the quality of life for citizens (Rogers [2]). Current urbanization processes significantly affect water and carbon cycles (Condon [3]) and leads to habitat and biodiversity destruction (Register [4]). In addition, cities also promote greater consumption of current limited natural resources- expected to peak shortly (Hubbert [5]). Today's cities are consuming three-quarters of the world's energy and emitting at least three-quarters of global pollutants (Rogers [2]). Every aspect of urban living has significant implications for the planet (Burdett and Fondazione La Biennale di Venezia [6](.

Moreover, in 2008, for the first time in history, the world urban population has equalled the world rural population and subsequently the world population will be urban in its majority (United Nations [7]). This worrying situation begs the question as to whether we are able to build cities which do not destroy or compromise the environment, but whether we are able to build cities that function as environmentally restorative elements; cities that contribute to, and truly improve existing urban environments.

Many attempts are being made in order to diminish and ameliorate these negative consequences. Studies are conducted on more efficient devices, low energy materials, more compact and walkable neighbourhoods, the use of green roofs within cities, promotion of green energy strategies and local food production, just to mention a few. But are these attempts making any significant difference?

This research believes we need more aggressive approaches in order to achieve significant results. As Jaime Lerner suggests, the solution is within cities themselves, and larger scale interventions are necessary. To address this imminent requirement, this research proposes an overall green living envelope intervention within existing cities (Fig 1).
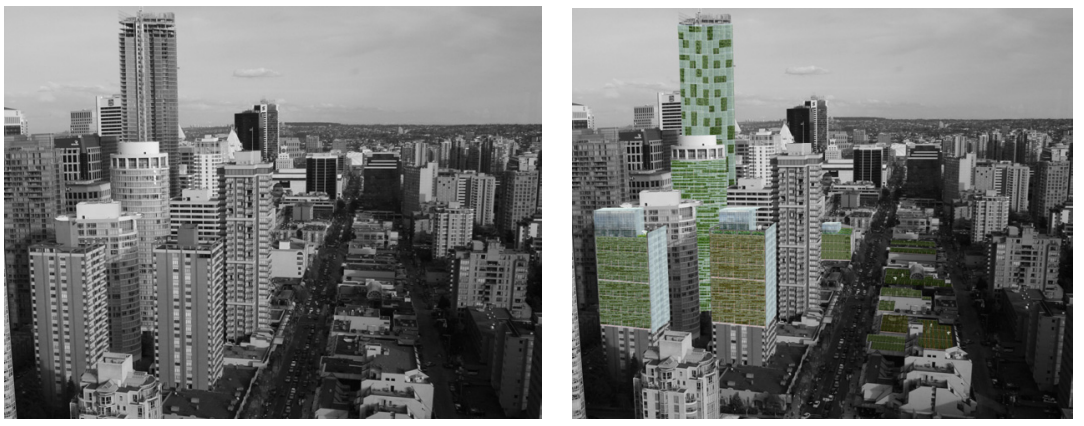

Figure 1: Overall green living envelope intervention [green façades + green roofs + green energy]. (Source: greenskinslab.)

It includes green roofs and green façades as a means of improving the urban environment, by reducing the energy demand of buildings, therefore contributing 
to more balanced soil, water and air qualities, as well as to urban biodiversity. Additionally, it includes an integration of green energy designs within existing urban surfaces - such as roofs and façades - in order to increase the resiliency and self-sufficiency of cities, lessen their dependence on oil and, promote carbon neutrality.

\section{Methodology}

In order to achieve specific quantitative results on the influence of such a green living envelope intervention, this research applies the suggested green intervention to a case study area within downtown Vancouver. The selected area is considered a representative of Downtown Vancouver, as it combines both residential buildings from the West End neighbourhood and commercial buildings from the Downtown District (Fig 2).
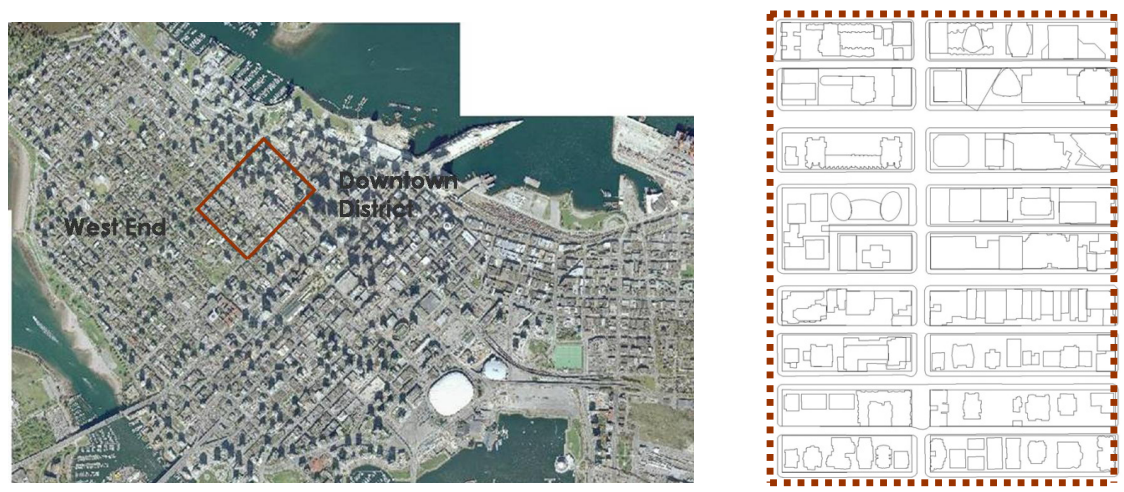

Figure 2: $\quad$ The selected site in downtown Vancouver combines the residential neighbourhood - West End - with the commercial Downtown District neighbourhood. (Source: greenskinslab.)

The research analyses existing properties of the site in terms of land use: green versus grey surfaces; current energy consumption by buildings based on their building type and uses; and $\mathrm{CO}_{2}$ emissions based on the energy source. It also calculates current flat roof and building façade areas (Table 1).

The research proposes to incorporate green living envelopes into the selected site by applying the Vancouver Green Factor. This green factor is based on similar green factor initiatives carried out in Europe and the U.S. These initiatives started in Berlin and Hamburg, Germany during the 1990s with the Biotope Area Factor (BAF) [10]. Similarly, the Greenspace Factor was recently implemented (2001) in an urban development in Malmö, Sweden [11]. Even more recently, in 2007, the City of Seattle developed its Green Factor [12]. These green factors establish some percentages of a specific area (from $30 \%$ to $60 \%$ depending on building types) that should be green in order to achieve minimum environmental values. They represent interesting initiatives since they 
Table 1: $\quad$ Characteristics of the selected site.

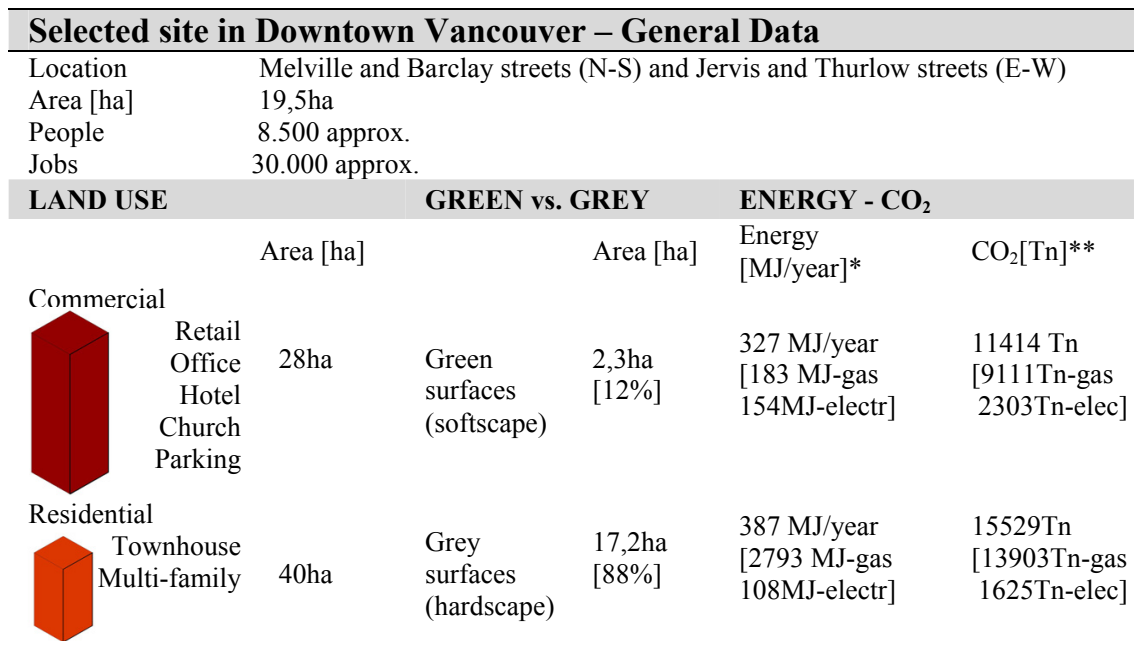

*The energy estimate is based on the report of the Residential Sector Climate Change Foundation Paper (Edwards et al., C., Adelaar, M., Cooper, K. [8]).

** $\mathrm{CO}_{2}$ emissions estimate assumes $1 \mathrm{GJ}$ natural gas emits $49,9 \mathrm{kgCO}_{2}$, and $1 \mathrm{GJ}$ electricity emits $15 \mathrm{kgCO}_{2}$ (The Sheltair Group Inc. [9]).

seek holistic interventions that this research advocates and in addition they are implemented in policies.

However, this research proposes the Vancouver Green Factor. This requires a minimum value of "0,3" for green surfaces, similar to what the Seattle Green Factor suggests, but it employs the green energy concept as well as all urban surfaces of the site including building façade areas. The research applies the Vancouver Green Factor to the selected area and analyses the benefits and influences of such a green living envelope intervention.

\section{Green living skins intervention}

The research applies the Vancouver Green Factor to the case study area. In order to achieve the proposed value of " 0,3 ", the existing urban fabric must increase its green surfaces by $60 \%$ over flat roof areas, $60 \%$ over sidewalk areas and $50 \%$ over façade areas (Fig 3 and Table 2).

To achieve the value suggested by the Green Factor, the proposed increase in green surface area also includes green energy. In this case, out of $50 \%$ of the greened façade area, $25 \%$ is combined with green energy; $10 \%$ with photovoltaic panels and $15 \%$ with thermal panels, which are facing south. Similarly, out of $60 \%$ of greened flat roof areas, $30 \%$ is combined with alternative energy solutions, $15 \%$ with photovoltaic panels and $15 \%$ with thermal panels.

The research analysis demonstrates both the environmental benefits achieved by such a green intervention as well as the energy achieved through green energy 
integration. Specifically, the research focuses on three main areas: energy savings, food and energy production.
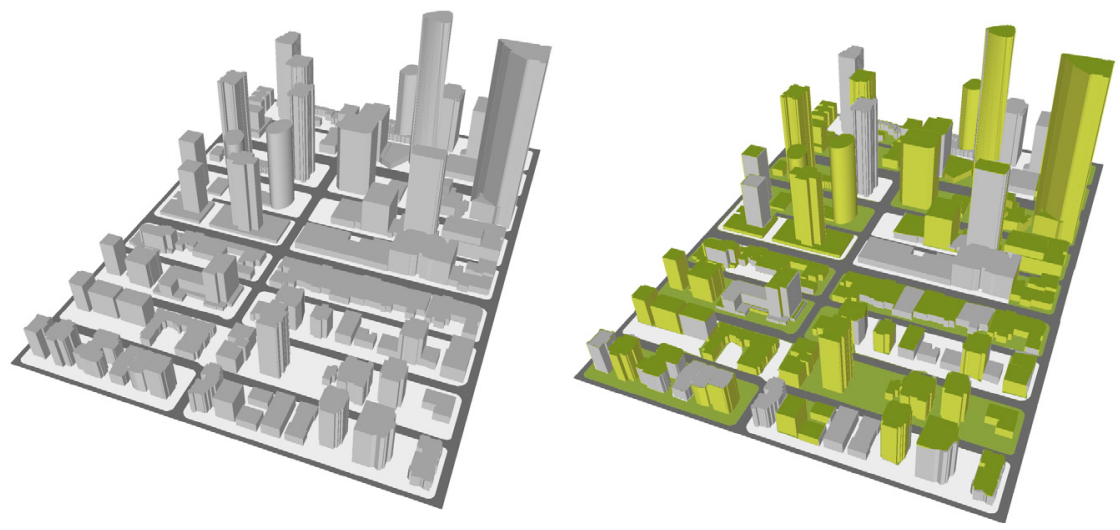

Figure 3: Greening existing urban surfaces of the case study area in order to achieve the value suggested by the Vancouver Green Factor. (Source: greenskinslab.)

Table 2: Application of the Vancouver Green Factor based on the Seattle Green Factor.

\section{Types of area - Downtown Vancouver}

$\mathrm{m}^{2} \quad$ factor total

A. Vegetation planted with a soil depth of less than 24 "

1 Lawn or grass pavers or ground covers [sf.]

$23.197,8$

0,2

$4.639,6$

B. Vegetation planted with a soil depth of more than 24"

4 Tree canopy for small/medium trees $-100 \mathrm{sf}$ per tree

5 Tree canopy for medium/large trees $-150 \mathrm{sf}$ per tree

8 Permeable paving that drains only in itself [sf] [60\% of existing]

C. Green Roofs -4 " minimum soil depth at time of planting [sf] [60\% of existing]

$3.245,0 \quad 0,3 \quad 973,5$

$3.245,0 \quad 0,4 \quad 1.298,0$

$13.221,3 \quad 0,6 \quad 7.932,8$

D. Vegetated walls [sf] [50\% of existing]

E. Water features (fountains) or rain gardens [sf]

$45.646,1 \quad 0,7 \quad 31.952,3$

$180.840,6 \quad 0,7 \quad 126.588,4$

0,7

Calculated green surfaces

$173.384,5$

Total urban surfaces of studied area [including facades]

$556.926,3$

Vancouver Green Factor of the proposed green intervention 


\subsection{Energy savings}

To estimate the energy savings achieved by the proposed green intervention, the research compiles different studies on the influence of greenery in reducing air temperature, as well as the influence of renovating houses by increasing the insulation within existing façades and roofs. Various research studies carried out by the Canada Mortgage and Housing Corporation suggest that a comprehensive "tune-up" of residential buildings can save up to $20 \%$ of annual energy and water costs (CMHC [13]). Similar studies focused on renovating ground oriented houses suggest that by improving insulation throughout the house envelope, energy savings could accrue to between 25\%-35\% (CMHC [14]).

The research also analyses a series of studies on the influence of greenery in reducing the energy demand by buildings. In this sense, research studies on green roofs suggest that the energy required for space conditioning due to the heat flow through the green roof would be reduced by more than $75 \%$ (Liu and Baskaran [15]). In the case of green walls, these contribute significantly to the reduction of indoor air temperature in the summer, by reducing the external air temperature of a west-facing façade up to $4^{\circ} \mathrm{C}$ on a clear August day in Japan; (Hoyano [16]) and by $5^{\circ} \mathrm{C}$, in South Africa (Holm [17]). This significant cooling capacity of plants could reduce the annual cooling energy use by $31 \%$, and windbreak plantings around unprotected homes would reduce annual heating energy use by $15 \%$ (McPherson et al. [18]). According to computer simulations, in a warm climate such as Madrid, cooling energy use reductions could reach up to $45 \%$ and heating reductions up to $23 \%$ (Laurenz [19]). In terms of the capacity of plants to trap air pollutants such as $\mathrm{CO} 2$; shrubby plants (on green roofs) would trap $8,76 \mathrm{~kg} / \mathrm{m}^{2}$; and climber plants (on green walls) would trap 6,57 $\mathrm{kg} / \mathrm{m}^{2}$ (Schaefer et al. [20]).

The research compiles information such as this, and consequently draws some assumptions from it. A key assumption is that green roofs and green façades, combined with green energy strategies, can reduce the energy demand by buildings by $20 \%$. Given this, it then calculates the final energy savings achieved by the proposed green living envelope intervention. Results show that such a green intervention contributes to a $17 \%$ savings in building energy demand.

\subsection{Food production}

The research includes an analysis on the potential of living roofs to produce local food (Fig 4). It assumes that Vancouverites consume $164 \mathrm{~kg}$ of vegetables per year (Statistics Canada [21]). The selected site contains 8.478 people- assuming 2,2 as the average number of persons per household (Census Statistics Canada [22]). The research proposes that half of the green roofs will be producing food in open air while the other half will be producing under greenhouses. Based on a series of studies, the research assumes that 1 ha of green roofs in open air would produce $12.886 \mathrm{~kg}$ of vegetables; while 1 ha under greenhouses would produce $318.860 \mathrm{~kg}$ of vegetables (Statistics Canada [23]).

Considering these numbers, the proposed green intervention would produce 757 tons of vegetables, which amounts to $54 \%$ of the vegetables consumed by 
the people living in the selected site. Assuming that $80 \%$ of the energy spent in vegetable production is due to transportation, processing, packaging, retailing, etc. (Heller and Keoleian [24]), this means that growing vegetables on the proposed living roofs would save $44 \%$ of energy spent for vegetable production. Considering that vegetable production represents $10 \%$ of the total food production in Canada (Statistics Canada [21]), this green intervention would reduce the energy consumed in food production by $4 \%$.
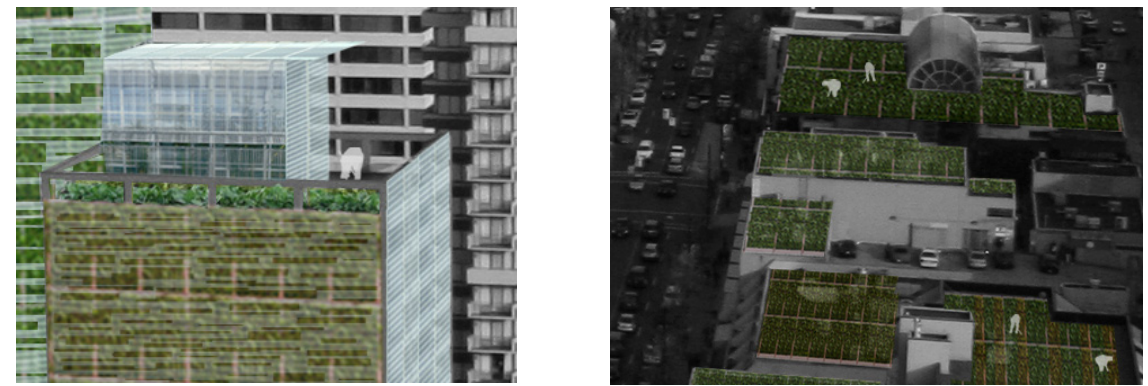

Figure 4: Examples of food production on proposed living roofs. (Source: greenskinslab.)

\subsection{Energy production}

The research also studies the potential energy produced by photovoltaic and thermal panels. It proposes that $10 \%$ of green façades and $15 \%$ of green roofs would be covered by photovoltaic panels, while $15 \%$ of green façades and $15 \%$ of green roofs would be covered by thermal panels. It analyses the energy achieved by these green energy panels. To this end, the research takes into account the specific solar characteristics of Vancouver, as well as the power capacity of photovoltaic panels (Pelland et al. [25]) and the annual heating amounts delivered by thermal panels (RETScreen [26]). This means $1 \mathrm{~m}^{2}$ of a photovoltaic panel with an average efficiency of $12 \%$, placed vertically and facing south, which requires a factor of 0.58 [27] would provide $70,2 \mathrm{kWh}$. Similarly $1 \mathrm{~m}^{2}$ of a vacuum-tube solar collector, placed vertically and facing south will deliver 338.6kWh (Viessmann [28]).

Based on these values the results achieved by the research in terms of the energy achieved by the proposed green energy envelopes suggest that proposed photovoltaic panels would cover $5 \%(13,571 \mathrm{GJ})$ of the total electricity consumed by the people living on the selected site. This is in comparison to proposed thermal panels, which would cover $22 \%$ of the heating demand. Combining these results means that the proposed green energy envelopes would deliver $16 \%$ of the total energy demanded by the site. 


\section{Conclusion/discussion}

This research shows the potential of a green living envelope intervention. It provides data on energy savings as well as on the influence of food and energy production. Results demonstrate that by incorporating vegetation and green energy retrofits into an existing urban fabric, in order to achieve the requirements suggested by the Vancouver Green Factor, the conventional energy demand by buildings would be reduced by $37 \%$ (16\% from green energy panels, $4 \%$ from food production, and $17 \%$ from the insulation capacity of vegetation). The combination of all these findings suggests that the proposed green intervention contributes to a $45 \%$ reduction in current $\mathrm{CO} 2$ emissions.

However, the research highlights the need for a more in-depth study of the specific benefits of vegetated envelopes, particularly on green walls, in order to achieve more accurate data. As a result, the research had to make some assumptions which need to be compared with more specific and detailed research on this issue. It suggests that the best way to achieve more accurate data is by monitoring green walls in terms of thermal performance- depending on the orientation- climate conditions, green wall systems, etc. This is the subsequent direction for the research.

\section{References}

[1] Lerner, J., "City is not a problem, city is solution". Keynote at the Ecocity World Summit 2008 Conference, April 23-26, 2008, San Francisco.

[2] Rogers, R., 1998. "Cities for a small planet". Westview Press, p.16, 27 , Colorado.

[3] Condon, P., et al., 2003. "Sustainable Urban Landscapes". University of British Columbia James Taylor Chair in Landscape and Liveable Environments, p. 10-13, Vancouver.

[4] Register, R., 2002. "Ecocities. Building cities in balance with nature". Berkeley Hills Books, p.26, Berkeley.

[5] Hubbert peak of oil production, http://www.hubbertpeak.com/ [accessed 9 May 2008]

[6] Burdett, R., Fondazione La Biennale di Venezia, 2006. "Cities architecture and Society" Rizzoli International, p.15, New York.

[7] United Nations, 2008. "World Urbanization Prospects. The 2007 Revision". http://www.un.org/esa/population/publications/wup2007/2007WUP_Highli ghts_web.pdf. New York, [accessed 28 February 2008]

[8] Edwards, C., Adelaar, M., Cooper, K., 1999. "Residential Sector Climate Change Foundation Paper". http://www.sheltair.com/ [accessed 11 December 2007]

[9] Edwards, C., Adelaar, M., Cooper, K., 1999. "Residential Sector Climate Change Foundation Paper". http://www.sheltair.com/ [accessed 11 December 2007] 
[10] Biotope Area Factor (BAF), 1994, Berlin, Germany. http://www.stadtentwicklung.berlin.de/umwelt/landschaftsplanung/bff/inde X_en.shtml

[11] Greenspace Factor, 2001, Malmö, Sweden. http://www.map21ltd.com/ scan-green/bo01.htm

[12] Green Factor, 2007, Seattle, US. http://www.seattle.gov/dpd/Permits /GreenFactor/

[13] CMHC, 2007. "Energy and Water Tune-ups. Multi-unit Residential Buidings". Produced by CMHC, printed in Canada.

[14] CMHC, 2004. "Renovating for energy savings". Produced by CMHC, printed in Canada.

[15] Liu, K., and Baskaran, B. 2003. "Thermal Performance of Green Roofs Through Field Evaluation”. North American Green Roof Infrastructure Conference. May 29-30, Chicago, Illinois.

[16] Hoyano, A. 1988. "Climatological Uses of Plants for Solar Control and the Effects on the Thermal Environment of a Building". Ed. Energy and Buildings. Vol 11, \#1-3, pp. 181-199. Tokyo.

[17] D. Holm. 1989. "Thermal Improvement by means of Leaf Cover on External Walls - A Simulation Model'. Ed. Energy and Buildings. Vol 14, pp. 19-30. South Africa.

[18] McPherson, E. G., Nowak, D. J., et al. 1993. “Chicago's Evolving Urban Forest: Initial report of the Chicago Urban Forest Climate Project". North-eastern Forest Experiment Station, pp 40-41. Radnor, Pennsylvania,

[19] Laurenz, J. 2005. "Natural Envelope: The green element as a boundary limit". The 2005 World Sustainable Building Conference. Tokyo.

[20] Schaefer, V., Rudd, H., Vala, J., 2004. "Urban Biodiversity“. Captus Press, Ontario.

[21] Statistics Canada 2002. "Food Consumption in Canada. Part II" www.statcan.ca [accessed January 2008]

[22] Census Statistics Canada 2006. www.statcan.ca [accessed May 2008]

[23] Statistics Canada 2008. "Fruit and Vegetable production", www.statcan.ca [accessed January 2008]

[24] Heller, M., and Keoleian, G., 2000. "Life-Cycle Based Sustainability Indicators for Assessment of the U.S. Food System" Center for Sustainable Systems, University of Michigan. http://www.umich.edu/ css

[25] Pelland, S., et al., 2006. "The Development Of Photovoltaic Resource Maps For Canada", 31st Annual Conference of the Solar Energy Society of Canada (SESCI), Aug. 20-24th 2006, Montréal, Canada.

[26] RETScreen ${ }^{\circledR}$ International, [www.retscreen.net]

[27] California Energy Commission, 2001."A Guide To Photovoltaic (Pv) System Design And Installation”. http://www.abcsolar.com/pdf/2001-0904_500-01-020.pdf

[28] Viessmann Technical Data Manual-VITOSOL 300-T, 2007 [http://www.viessmann-us.com/web/canada/ca_publish.nsf/Attachments ByTitle/dbl-vitosol-300.pdf/\$FILE/Vitosol-300-TDM.pdf] 